\title{
PENGARUH CITRA MEREK, HARGA, DAN KUALITAS PRODUK TERHADAP LOYALITAS KONSUMEN DUNKIN' DONUTS MANADO TOWN SQUARE
}

\author{
Putri Gianny Erdipriwiranti \\ Paulus Adrian Pangemanan \\ Grace Adonia Josefina Rumagit
}

\begin{tabular}{ll}
\hline Naskah diterima melalui Website Jurnal Ilmiah agrisosioekonomi@ unsrat.ac.id & : Sabtu, 13 Juli 2019 \\
Disetujui diterbitkan & : Kamis, 25 Juli 2019 \\
\hline
\end{tabular}

\begin{abstract}
This study aims to analyze how influential the brand image, price, and product quality are on consumer loyalty at Dunkin' Donuts Manado Town Square. This research was conducted for 1 month, starting from April to May 2019. Primary data was obtained from 96 respondents who were collected through filling out the prepared questionnaire in advance. Sample selection is done using accidental sampling method. Secondary data was obtained through information from the Dunkin' Donuts company, from the internet through google search and google scholar to get articles, journals and theses related to the topic of research on consumer loyalty. The analysis used is multiple linear regression analysis. The results show that brand image, price, and product quality together influence consumer loyalty. Brand image, price, and product quality individually have a positive and significant effect on consumer loyalty. Brand image, price, and product quality have an effect of 47.9 percent on consumer loyalty, and the remaining 52.1 percent is influenced by other factors. ${ }^{*}$ eprm*
\end{abstract}

Keywords: brand image, consumers' loyalty, Dunkin 'Donuts, Manado Town Square

\begin{abstract}
ABSTRAK
Penelitian ini bertujuan untuk menganalisis seberapa berpengaruh citra merek, harga, dan kualitas produk terhadap loyalitas konsumen di Dunkin' Donuts Manado Town Square. Penelitian ini dilaksanakan selama 1 bulan, mulai dari bulan April sampai Mei 2019. Data primer diperoleh dari 96 responden yang dikumpulkan melalui pengisian kuesioner yang telah disiapkan terlebih dahulu. Pemilihan sampel dilakukan dengan menggunakan metode pemilihan sampel secara kebetulan (accidental sampling). Data sekunder diperoleh melalui informasi dari perusahaan Dunkin' Donuts, dari internet melalui google search dan google scholar untuk mendapatkan artikel, jurnal dan skripsi yang berkaitan dengan topik penelitian tentang loyalitas konsumen. Analisis yang dipakai adalah analisis regresi linear berganda. Hasil penelitian menunjukkan citra merek, harga, dan kualitas produk secara bersama-sama berpengaruh terhadap loyalitas konsumen. Citra merek, harga, dan kualitas produk secara individu berpengaruh positif dan signifikan terhadap loyalitas konsumen. Citra merek, harga, dan kualitas produk berpengaruh sebesar 47,9 persen terhadap loyalitas konsumen, dan sisanya 52,1 persen dipengaruhi oleh faktor lain. ${ }^{*}{ }^{2}{ }^{*}$
\end{abstract}

Kata kunci: citra merek, loyalitas konsumen, Dunkin’ Donuts, Manado Town Square 


\section{PENDAHULUAN}

\section{Latar Belakang}

Perkembangan dan persaingan dalam dunia perdagangan berkembang semakin pesat, hal itu terlihat dari semakin banyaknya perusahaan dengan berbagai inovasi dalam memasarkan produk. Untuk menarik minat konsumen dalam melakukan pembelian terhadap suatu produk, para pelaku bisnis dituntut lebih kreatif dan inovatif agar dapat bertahan di tengah persaingan yang semakin ketat. Tak hanya itu, berbagai produk yang ditawarkan di pasar perlu diperhatikan oleh perusahaan karena situasi pasar yang sulit untuk diprediksi. Dalam menghadapi persaingan pasar yang ada, perusahaan harus mampu menciptakan produk yang memiliki suatu identitas tersendiri, harga yang bisa diterima oleh konsumen, dan kualitas produk yang mampu membuat konsumen merasa puas sehingga hal ini menjadi kekuatan bagi perusahaan dalam persaingan yang ada untuk menciptakan loyalitas konsumen.

Menurut Tjiptono (2008), loyalitas konsumen yaitu situasi dimana konsumen berperilaku positif kepada produk atau produsen (penyedia jasa) dan disertai pola pembelian yang konsisten. Dan menurut Sangadji dan Sopiah (2013) menyatakan bahwa loyalitas konsumen adalah komitmen pelanggan bertahan secara mendalam untuk berlangganan kembali atau melakukan pembelian ulang produk atau jasa terpilih secara konsisten di masa yang akan datang, meskipun pengaruh situasi dan usaha-usaha pemasaran mempunyai potensi untuk menyebabkan perubahan perilaku.

Salah satu bisnis yang menjanjikan adalah bisnis di bidang kuliner/makanan seperti donat. Donat merupakan salah satu jenis makanan yang popular di tengah masyarakat Indonesia. Saat ini, di Kota Manado sudah banyak toko atau gerai donat yang mudah ditemukan dan berdiri diberbagai pusat keramaian seperti pusat perbelanjaan atau yang biasa disebut mall. Berbagai gerai atau toko donut seperti Dunkin' Donuts, J.CO Donuts and Coffee, Dolphin Donuts, dan Mokko Factory, dan para penjual donat kaki lima. Hal tersebut membuat pelaku usaha harus bersaing untuk mendapatkan konsumen untuk membeli produk mereka. Selain bersaing untuk mendapatkan konsumen, pemilik usaha juga harus berusaha untuk melakukan inovasi atau perubahan agar menjadi lebih unggul dari para pesaingnya. Awalnya, donat disajikan dengan varian rasa terbatas yaitu dengan gula halus, meises, ataupun selai coklat. Dalam perkembangannya, donat mulai disajikan dengan berbagai varian rasa/topping. Begitu pula dengan Dunkin' Donuts yang menjual donat dengan berbagai varian rasa/topping.Dunkin' Donuts adalah restoran dan waralaba makanan internasinal yang mengkhususkan dalam produk donat. Dunkin' Donuts saat ini masih dipilih konsumen sebagai pilihan untuk menikmati donat dengan berbagai varian rasa sambil bersantai dan berkumpul bersama teman ataupun keluarga. Meskipun masih diminati konsumen sebagai tempat untuk bersantai dan berkumpul bersama, tetapi masih ada keluhan dari para konsumen Dunkin' Donuts seperti harga, kualitas produk, ragam produk, rasa dan suasana toko yang masih dirasa kurang memuaskan konsumen sehingga hal-hal tersebut berimbas pada keputusan pembelian produk Dunkin Donuts.

\section{Rumusan Masalah}

Berdasarkan latar belakang yang telah diuraikan, maka perumusan masalah yang muncul adalah:

1. Apakah citra merek berpengaruh positif terhadap loyalitas konsumen pada produk Dunkin' Donuts Manado Town Square?

2. Apakah harga berpengaruh positif terhadap loyalitas konsumen pada produk Dunkin' Donuts Manado Town Square?

3. Apakah kualitas produk berpengaruh positif terhadap loyalitas konsumen pada produk Dunkin' Donuts Manado Town Square?

\section{Tujuan Penelitian}

Adapun tujuan dari penelitian ini adalah menganalisis pengaruh citra merek, harga, dan kualitas produk terhadap loyalitas konsumen di Dunkin' Donuts Manado Town Square. 


\section{Manfaat Penelitian}

Ada beberapa manfaat yang dapat diperoleh dari penulisan ilmiah ini, seperti:

1. Bagi peneliti, penelitian ini sebagai salah satu karya ilmiah untuk mengembangkan pengetahuan dan wawasan mengenai loyalitas konsumen.

2. Bagi pihak Dunkin' Donuts, dapat menjadi bahan masukan yang bermanfaat bagi bisnis Dunkin' Donuts.

3. Bagi pihak lain, diharapkan dapat menambahkan wawasan dan pengetahuan serta dapat dijadikan acuan dan informasi untuk penelitian selanjutnya.

\section{METODE PENELITIAN}

\section{Tempat dan Waktu Penelitian}

Penelitian ini dilaksanakan di cabang outlet Dunkin' Donuts yaitu di Manado Town Square 2. Penelitian ini dilakukan selama 1 bulan yaitu mulai bulan April sampai bulan Mei 2019.

\section{Teknik Pengumpulan Sampel}

Penelitian ini menggunakan accidental sampling. Accidental sampling adalah teknik penentuan sampel berdasarkan kebetulan, yaitu konsumen yang secara kebetulan/insidental bertemu dengan peneliti dapat digunakan sebagai sampel, bila dipandang orang yang kebetulan ditemui itu cocok sebagai sumber data (Sugiyono, 2009). Sampel yang digunakan dalam penelitian ini sebanyak 96 orang dari 2.250 populasi.

\section{Teknik Pengumpulan Data}

Data yang digunakan dalam penelitian ini adalah data primer dan data sekunder. Data primer merupakan data yang diperoleh langsung oleh peneliti dari wawancara dengan menggunakan kuisioner kepada konsumen di lapangan, sedangkan data sekunder adalah data yang diperoleh dari perusahaan Dunkin' Donuts, buku, dan jurnal. Teknik pengumpulan data yang digunakan dalam penelitian ini adalah:

1. Observasi

2. Pencatatan
Konsep Pengukuran Variabel

Adapun konsep pengukuran variabel dalam penelitian ini adalah sebagai berikut:

1. Karakteristik Responden

a. Jenis kelamin (Laki-laki/ Perempuan).

b. Usia (tahun).

c. Pekerjaan (profesi responden pada saat wawancara dilaksanakan).

d. Pendidikan terakhir (pendidikan terakhir yang telah ditempuh oleh responden pada saat wawancara dilaksanakan).

e. Penghasilan (penghasilan setiap bulan).

f. Frekuensi berkunjung (banyaknya kunjungan yang telah dilakukan responden dalam jangka waktu 1 bulan terakhir)

2. Variabel-variabel yang diukur, yaitu:

a. Citra merek $\left(\mathrm{X}_{1}\right)$

Variabel citra merek adalah apa yang konsumen pikirkan dan rasakan ketika mendengar atau melihat merek Dunkin' Donuts.

Indikator pertanyaan:

a) Reputasi merek di mata konsumen: reputasi merek baik atau buruk di mata konsumen.

b) Merek yang mudah dikenali: merek mudah dikenali oleh konsumen atau tidak.

c) Kepercayaan terhadap merek: konsumen percaya terhadap merek Dunkin' Donuts atau tidak.

d) Merek memiliki ciri khas: merek memiliki ciri khas tersendiri dengan pesaing yang memproduksi produk yang sejenis atau tidak.

b. Harga $\left(\mathrm{X}_{2}\right)$

Variabel harga adalah persepsi konsumen terhadap kebijakan harga yang diterapkan oleh Dunkin' Donuts dalam menjual produknya.

Indikator pertanyaan:

a) Harga terjangkau: harga produk terjangkau atau tidak.

b) Kesesuaian harga: harga sesuai dengan produk yang didapatkan atau tidak.

c) Harga bersaing: harga yang diterapkan bersaing dengan produk dari perusahaan lain yang sejenis atau tidak. 
d) Potongan harga (diskon): pada waktu tertentu Dunkin' Donuts memberikan potongan harga (diskon) atau tidak.

e) Kemudahan dalam bertransaksi: pemilihan cara pembayaran beragam misalnya tunai, kartu kredit, dan kartu debit

c. Kualitas produk $\left(\mathrm{X}_{3}\right)$

Variabel kualitas produk adalah bentuk penilaian atas produk yang akan dibeli dengan melihat tingkat kualitas atau performa dari produk tersebut.

Indikator pertanyaan:

a) Daya tahan: produk memiliki daya tahan yang tinggi atau tidak.

b) Rasa yang berkualitas: produk memiliki rasa yang berkualitas atau tidak.

c) Memberikan kepuasan: produk memuaskan keinginan konsumen atau tidak.

d) Keragaman varian produk: varian produk yang disajikan beragam atau tidak.

e) Estetika: produk yang disajikan menarik atau tidak

d. Loyalitas konsumen (Y)

Variabel loyalitas konsumen merupakan tindakan konsumen dalam melakukan pembelian berulang terhadap suatu produk meskipun terdapat produk lain yang hampir sama

Indikator pertanyaan:

a) Loyalitas konsumen: kesediaan konsumen dalam melakukan pembelian berulang dan tidak berpindah ke merek produk lain yang sejenis.

b) Ketertarikan konsumen: ketertarikan konsumen dalam membeli produk.

c) Memperkenalkan produk: kesediaan konsumen untuk memperkenalkan produk ke orang lain.

d) Merekomendasikan kesediaan konsumen untuk merekomendasikan produk Dunkin' Donuts ke konsumen lain agar konsumen lain juga membeli produk Dunkin' Donuts.

\section{Skala Likert}

Skala likert adalah teknik pengukuran sikap yang paling luas digunakan dalam riset pemasaran. Dengan menggunakan skala likert, maka variabel yang akan diukur dijabarkan menjadi dimensi, dimensi dijabarkan menjadi indikator-indikator yang dapat diukur.

\section{Metode Analisis Data}

Metode analisis data yang digunakan adalah analisis regresi linear berganda. Analisis regresi linear berganda merupakan statistik yang digunakan untuk mengetahui bagaimana keadaan atau pengaruh variabel independen terhadap variabel dependen

\section{HASIL DAN PEMBAHASAN}

\section{Deskripsi Umum Dunkin’ Donuts}

Di Kota Manado, Dunkin' Donuts telah memiliki beberapa gerai seperti Dunkin' Donuts Sam Ratulangi, Dunkin' Donuts Manado Town Square II, dan Dunkin' Donuts Bandara Sam Ratulangi. Dunkin' Donuts Manado Town Square pertama kali beroperasi pada tanggal 16 Februari 2012. Lokasi dari Dunkin' Donuts Manado Town Square dapat dikatakan strategis karena lokasi tersebut berada didalam tempat pusat perbelanjaan yang ramai dikunjungi oleh konsumen. Letak gerai Dunkin' Donuts Manado Town Square pun disebelah pintu keluar/ masuk lobby utama Manado Town Square II sehingga sering dilalui oleh pengunjung Manado Town Square II. Gerai Dunkin' Donuts Manado Town Square dapat dikatakan sangat nyaman bagi konsumen karena tersedianya ac, free wifi, tv, tempat duduk berupa sofa yang nyaman, tersedia smoking area, dan konsumen juga bisa melihat proses pembuatan donat melalui dinding kaca.

Menu utama yang tersedia di Dunkin' Donuts Manado Town Square adalah sajian donat menggunakan aneka topping dan berbagai minuman berbagai rasa. Produk Dunkin' Donuts Manado Town Square terdiri dari: 
a. Makanan

\section{Donuts Classics}

Donuts classics terdiri dari choco peanut butter, icy cool blueberry, chocolate filling, blueberry frosted, dpcb, smiley, strawberry frost, dan choco marble.

\section{Donuts Fancies}

Donuts fancies terdiri dari black cheese topping dan cheese topping.

b. Minuman

\section{Regular Beverages}

Regular beverages terdiri dari hot coffee, hot tea, hot milk, hot cappuccino, hot espresso, dan hot chocolate.

\section{Premier Beverages}

Premier beverages terdiri dari iced tea, orange juice, lemon tea, green tea, milk tea, thai tea, blueberry punch, iced chocolate, ice cappuccino, iced coffee, caffe latte (hazelnut, vanilla, dan caramel).

Harga yang ditawarkan terbilang mahal dibandingkan dengan harga pesaingnya. Harga untuk satu buah donat sebesar Rp. 10.400,namun harganya akan lebih murah jika konsumen membeli sebanyak setengah lusin atau satu lusin. Dapat dilihat pada Tabel 1.

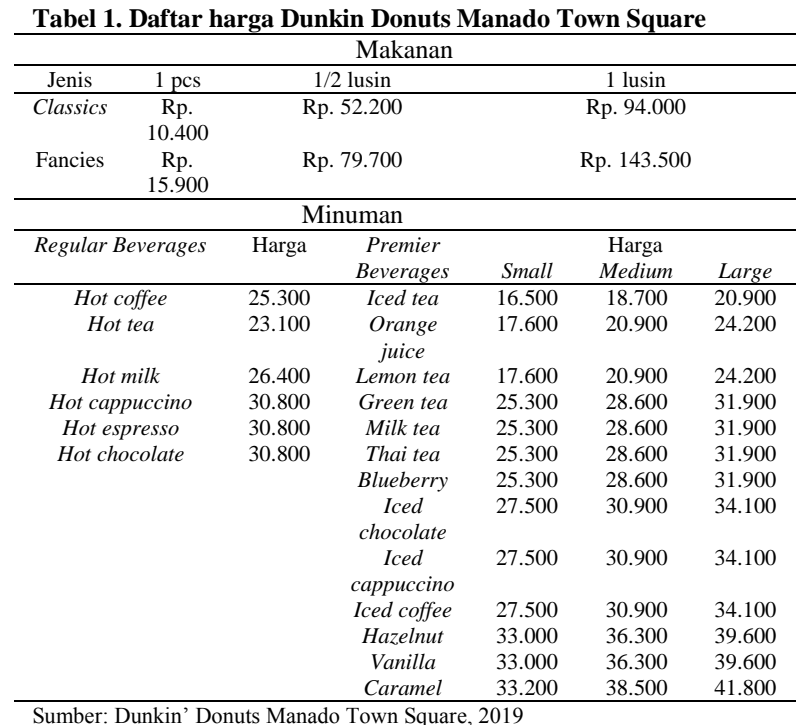

$$
\text { Meskipun harga Dunkin' Donuts }
$$
terbilang mahal, namun Dunkin' Donuts sering mengadakan berbagai promosi agar dapat menarik konsumen dalam melakukan pembelian. Berikut bentuk promosi yang dilakukan oleh Dunkin' Donuts:
1. Pemilik Kartu Member DD Card

Program ini dikhusukan bagi konsumen yang memiliki kartu member DD Card. Kartu member DD Card biasa didapatkan dengan membeli produk Dunkin' Donuts dengan pembelian minimal Rp. 200.000. Pengguna kartu member DD Card akan mendapatkan potongan harga (diskon) sebesar 20\% di hari Rabu dan $10 \%$ untuk setiap hari. Pengguna DD Card juga diberikan program khusus yaitu Happy Monday and Tuesday yaitu promo setiap hari Senin dan Selasa, promo tersebut berubah-ubah setiap minggunya, biasanya konsumen mendapatkan promo beli 1 minuman dan mendapatkan 1 minuman gratis, atau membeli 7 buah donat akan mendapatkan tambahan 5 donat gratis.

2. Pengguna Kartu Debit atau Kredit BCA

Bagi pengguna kartu debit atau kredit BCA mendapatkan penawaran khusus yaitu membeli 1 minuman akan mendapatkan 1 minuman gratis di hari Jumat sampai Minggu.

3. Pengguna Telkomsel

Promo ini berlaku bagi pengguna Telkomsel yang mendapatkan pesan singkat dari Dunkin' Donuts berupa promo membeli 6 donat akan mendapatkan gratis 6 donat.

4. Pengguna LINE

Promo ini berlaku bagi pengguna aplikasi LINE yang mendapatkan pesan singkat melalui aplikasi LINE dari Dunkin' Donuts berupa kupon potongan harga.

\section{Karakteristik Responden}

\section{Karakteristik Responden berdasarkan Jenis Kelamin}

Karakteristik responden berdasarkan jenis kelamin terdiri dari laki-laki dan perempuan yang dapat dilihat pada Tabel 2.

Tabel 2. Karakteristik Responden Berdasarkan Jenis Kelamin

\begin{tabular}{cccc}
\hline No & $\begin{array}{c}\text { Jenis } \\
\text { Kelamin }\end{array}$ & $\begin{array}{c}\text { Jumlah } \\
\text { (Orang) }\end{array}$ & Persentase (\%) \\
\hline 1 & Laki-laki & 26 & 27,08 \\
2 & Perempuan & 70 & 72,92 \\
\hline & Total & 96 & 100 \\
\hline
\end{tabular}

Sumber : Diolah dari data primer, 2019 
Mayoritas responden berjenis kelamin perempuan yaitu sebanyak 70 responden $(72,92 \%)$, berarti bahwa konsumen yang loyal paling dominan adalah responden berjenis kelamin perempuan dan selebihnya adalah responden berjenis kelamin laki-laki yaitu sebanyak 26 responden (27,08\%). Jumlah responden perempuan lebih dominan daripada laki-laki dikarenakan perempuan pada umumnya lebih menyukai menghabiskan waktu di tempat seperti Dunkin' Donuts dibandingkan laki-laki. Selain itu, perempuan lebih sering memanfaatkan promo-promo yang diberikan dibandingkan laki-laki.

\section{Karakteristik Responden Berdasarkan Usia}

Penyajian data responden berdasarkan tingkatan usia dapat dilihat pada Tabel 3.

Tabel 3. Karakteristik Responden Berdasarkan Usia

\begin{tabular}{cccc}
\hline No & Usia (Tahun) & Jumlah (Orang) & Persentase $(\%)$ \\
\hline 1 & $16-23$ & 36 & 37.5 \\
2 & $24-31$ & 37 & 38.5 \\
3 & $32-39$ & 15 & 15.6 \\
4 & $40-47$ & 6 & 6.25 \\
5 & $48-55$ & 2 & 2.1 \\
\hline & Total & 96 & 100 \\
\hline
\end{tabular}

Sumber : Diolah dari data primer, 2019

Tabel 3 menunjukkan bahwa konsumen Dunkin' Donuts yang terbanyak adalah berusia 24-31 yaitu sebanyak 37 orang $(38,5 \%)$. Pada tingkatan usia 24-31 merupakan responden yang telah memiliki pekerjaan dan penghasilan yang cukup sehingga mampu membeli produk Dunkin' Donuts tanpa perlu memikirkan harga. Pada tingkatan usia 16-23 dengan jumlah responden 36 orang $(37,5)$ merupakan usia sekolah sehingga banyak pelajar dan mahasiswa yang menghabiskan waktu sepulang sekolah atau kuliah untuk menikmati donat sambil berkumpul bersama teman. Pada tingkatan usia 32-39 sebanyak 15 orang $(15,6 \%), 40-47$ sebanyak 6 orang $(6,25 \%)$, dan $48-55$ sebanyak 2 orang $(2,1 \%)$ cenderung memiliki pertimbangan bahwa donat yang memiliki topping mengandung kadar gula yang tinggi sehingga lebih selektif dalam memilih produk yang akan dikonsumsi.

\section{Karakteristik Responden Berdasarkan Jenis Pekerjaan}

Penyajian data responden berdasarkan jenis pekerjaan dapat dilihat pada Tabel 4 .

Tabel 4. Karakteristik Responden Berdasarkan Jenis Pekerjaan

\begin{tabular}{clcc}
\hline No & \multicolumn{1}{c}{ Pekerjaan } & $\begin{array}{c}\text { Jumlah } \\
(\text { Orang) }\end{array}$ & $\begin{array}{c}\text { Persentase } \\
(\%)\end{array}$ \\
\hline 1 & $\begin{array}{l}\text { Pelajar/ } \\
\text { Mahasiswa }\end{array}$ & 25 & 26.04 \\
2 & PNS/ TNI/ & 16 & 16.67 \\
& POLRI & & \\
3 & Pegawai Swasta & 23 & 23.96 \\
4 & Wiraswasta & 21 & 21.88 \\
5 & Tidak Bekerja & 11 & 11.46 \\
\hline \multicolumn{2}{l}{ Total } & 96 & 100 \\
\hline Sumber : Diolah dari data primer, 2019
\end{tabular}

Tabel 4 menunjukkan bahwa responden terbanyak adalah pelajar/ mahasiswa sebanyak 25 orang $(26,04)$. Hal ini disebabkan karena banyak pelajar/ mahasiswa yang sering menghabiskan waktunya sepulang sekolah atau kuliah untuk berkumpul bersama teman di Dunkin' Donuts atau untuk mengerjakan tugas sekolah atau kuliah. Sedangkan responden yang terendah adalah ibu rumah tangga sebanyak 11 orang $(11,46 \%)$, hal ini dikarenakan ibu rumah tangga tidak terlalu sering mengunjungi tempat seperti Dunkin' Donuts dan lebih banyak di rumah untuk mengurus rumah. Namun, jika disimpulkan secara keseluruhan, mayoritas konsumen Dunkin Donuts merupakan konsumen yang telah memiliki pekerjaan (bukan pelajar/ mahasiswa).

\section{Karakteristik Responden Berdasarkan Pendidikan Terakhir}

Pendidikan terakhir adalah tingkat pendidikan yang paling akhir yang telah diselesaikan atau ditamatkan seseorang. Penyajian data responden berdasarkan pendidikan terakhir dapat dilihat pada Tabel 5.

Tabel 5. Karakteristik Responden Berdasarkan Pendidikan Terakhir

\begin{tabular}{clcc}
\hline No & Pendidikan Terakhir & Jumlah (Orang) & Persentase (\%) \\
\hline 1 & <SMA & 9 & 9.38 \\
2 & SMA/ SEDERAJAT & 36 & 37.5 \\
3 & D3 & 4 & 4.17 \\
4 & S1 & 47 & 48.96 \\
\hline & Total & 96 & 100 \\
\hline
\end{tabular}

Sumber : Diolah dari data primer, 2019 
Tabel 5 menunjukkan bahwa responden terbanyak yang melakukan pembelian di Dunkin Donuts merupakan lulusan S1 sebanyak 47 orang $(48,96 \%)$. Hal ini disebabkan karena mayoritas konsumen Dunkin Donuts merupakan konsumen dengan usia 24-31, usia tersebut pada umumnya telah menyelesaikan atau menamatkan pendidikan di bangku perkuliahan (S1). Responden dengan pendidikan terakhir D3 merupakan jumlah responden terendah sebanyak 4 orang $(4,17 \%)$.

\section{Karakteristik Responden Berdasarkan Penghasilan}

Penyajian data responden berdasarkan penghasilan dapat dilihat pada Tabel 6 .

\begin{tabular}{|c|c|c|c|}
\hline No & Penghasilan (Rp) & Jumlah (Orang) & Persentase $(\%)$ \\
\hline 1 & 0 & 35 & 36.46 \\
\hline 2 & $<1.000 .000$ & 0 & 0 \\
\hline 3 & $2.000 .000-3.000 .000$ & 11 & 11.46 \\
\hline 4 & $3.000 .000-5.000 .0000$ & 29 & 30.21 \\
\hline 5 & $>5.000 .000$ & 21 & 21.88 \\
\hline & Total & 96 & 100 \\
\hline
\end{tabular}

Sumber : Diolah dari data primer, 2019

Tabel 6 menunjukkan bahwa responden yang tidak memiliki penghasilan merupakan responden terbanyak yang melakukan pembelian di Dunkin Donuts dengan jumlah responden sebanyak 35 orang $(36,46 \%)$. Responden tersebut merupakan responden yang belum memiliki pekerjaan atau masih berstatus sebagai pelajar/ mahasiswa sehingga belum memiliki penghasilan tetap. Uang yang digunakan untuk membeli produk Dunkin Donuts didapatkan dari orang lain seperti orang tua responden. Selain pelajar/ mahasiswa, ibu rumah tangga juga tidak memiliki penghasilan tetap, uang yang digunakan untuk membeli produk Dunkin Donuts didapatkan dari suami responden. Sedangkan yang memiliki penghasilan dibawah $\mathrm{Rp} 1.000 .000$, tidak ada dalam responden.

\section{Karakteristik Responden Berdasarkan Frekuensi Berkunjung}

Penyajian data responden berdasarkan frekuensi berkunjung adalah sebagai berikut

\begin{tabular}{|c|c|c|c|}
\hline No & Kunjungan & Jumlah (Orang) & Persentase (\%) \\
\hline 1 & 5 & 27 & 28.13 \\
\hline 2 & 6 & 8 & 8.33 \\
\hline 3 & 7 & 10 & 10.42 \\
\hline 4 & 8 & 5 & 5.21 \\
\hline 5 & $>10$ & 46 & 47.92 \\
\hline \multicolumn{2}{|r|}{ Total } & 96 & 100 \\
\hline
\end{tabular}

Sumber : Diolah dari data primer, 2019
Total berkunjung responden dalam jangka waktu 1 bulan yang paling banyak adalah lebih dari 10 kali berkunjung dalam waktu 1 bulan sebanyak 46 orang $(47,92 \%)$. Hal ini dikarenakan konsumen tersebut dalam 1 minggu pasti membeli produk Dunkin Donuts. Responden yang lebih dari $10 \mathrm{kali}$ datang membeli produk Dunkin Donuts telah menjadi konsumen Dunkin Donuts selama bertahun-tahun dan merasa bahwa produk yang diberikan oleh Dunkin Donuts memiliki rasa yang enak. Sedangkan frekuensi berkunjung yang terendah adalah 8 kali sebanyak 5 orang $(5,21 \%)$.

\section{Uji Instrumen}

\section{Uji Validitas}

Semua item pernyataan yang digunakan untuk mengukur variabel-variabel yang digunakan dalam penelitian ini mempunyai koefisien korelasi yang lebih besar dari $r$ tabel. Untuk sampel sebanyak 96 responden, yaitu 0,169. Dari hasil tersebut menunjukkan bahwa semua item pernyataan (indikator) adalah valid. Dapat dilihat pada Tabel 8.

Tabel 8. Uji Validitas

\begin{tabular}{|c|c|c|c|c|}
\hline No & Variabel & r hitung & $r$ tabel & Keterangan \\
\hline 1 & $\begin{array}{l}\text { Citra Merek } \\
-X_{1} .1 \\
-X_{1} .2 \\
-X_{1} .3 \\
-X_{1} .4\end{array}$ & $\begin{array}{l}0,723 \\
0,751 \\
0,548 \\
0,397\end{array}$ & $\begin{array}{l}0,169 \\
0,169 \\
0,169 \\
0,169\end{array}$ & $\begin{array}{l}\text { Valid } \\
\text { Valid } \\
\text { Valid } \\
\text { Valid }\end{array}$ \\
\hline 2 & $\begin{array}{l}\text { Harga } \\
-X_{2} .1 \\
-X_{2} .2 \\
-X_{2} .3 \\
-X_{2} .4\end{array}$ & $\begin{array}{l}0,716 \\
0,768 \\
0,796 \\
0,604\end{array}$ & $\begin{array}{l}0,169 \\
0,169 \\
0,169 \\
0,169\end{array}$ & $\begin{array}{l}\text { Valid } \\
\text { Valid } \\
\text { Valid } \\
\text { Valid }\end{array}$ \\
\hline 3 & $\begin{array}{l}\text { Kualitas } \\
\text { Produk } \\
-X_{3} .1 \\
-X_{3} .2 \\
-X_{3} .3 \\
-X_{3} .4 \\
-X_{3} .5\end{array}$ & $\begin{array}{l}0,595 \\
0,853 \\
0,802 \\
0,646 \\
0,763\end{array}$ & $\begin{array}{l}0,169 \\
0,169 \\
0,169 \\
0,169 \\
0,169\end{array}$ & $\begin{array}{l}\text { Valid } \\
\text { Valid } \\
\text { Valid } \\
\text { Valid } \\
\text { Valid }\end{array}$ \\
\hline 4 & $\begin{array}{l}\text { Loyalitas } \\
\text { Konsumen } \\
\text { - Y.1 } \\
\text { - Y.2 } \\
\text { - Y.3 } \\
\text { - Y.4 }\end{array}$ & $\begin{array}{l}0,758 \\
0,728 \\
0,846 \\
0,814\end{array}$ & $\begin{array}{l}0,169 \\
0,169 \\
0,169 \\
0,169\end{array}$ & $\begin{array}{l}\text { Valid } \\
\text { Valid } \\
\text { Valid } \\
\text { Valid }\end{array}$ \\
\hline
\end{tabular}




\section{Uji Reliabilitas}

Hasil uji reliabilitas tersebut menunjukkan bahwa semua variabel mempunyai koefisien Alpha diatas 0,60 sehingga dapat disimpulkan bahwa semua item-item pengukur variabel dari kueisioner adalah reliabel atau konsisten. Dapat dilihat pada Tabel 9.

Tabel 9. Uji Reliabilitas

\begin{tabular}{|c|c|c|}
\hline Variabel & Alpha & Keterangan \\
\hline Citra Merek & 0,662 & Reliabel \\
\hline Harga & 0,682 & Reliabel \\
\hline Kualitas Produk & 0,783 & Reliabel \\
\hline Loyalitas Konsumen & 0,788 & Reliabel \\
\hline
\end{tabular}

\section{Analisis Regresi Linear Berganda}

Analisis regresi linear berganda digunakan untuk mengetahui seberapa besar pengaruh variabel bebas yang terdiri dari citra merek, harga, dan kualitas produk terhadap variabel terikat yaitu loyalitas konsumen.

\begin{tabular}{|c|c|c|c|}
\hline Model & Variabel yang Dimasukkan & $\begin{array}{c}\text { Variabel yang } \\
\text { Dibuang }\end{array}$ & Metode \\
\hline 1 & $\begin{array}{l}\text { KUALITAS PRODUK, } \\
\text { HARGA, CITRA MEREK }\end{array}$ & 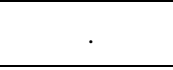 & Masuk \\
\hline
\end{tabular}

Tabel 10 menunjukkan bahwa seluruh variabel independen dimasukkan dalam analisis ini, atau dengan kata lain tidak ada variabel independen yang tidak digunakan, atau disebut metode enter.

\begin{tabular}{|c|c|c|c|c|c|c|}
\hline \multicolumn{7}{|c|}{ Kesalahan } \\
\hline & & B & Std. & Beta & $\mathrm{T}$ & Sig. \\
\hline 1 & CITRA MEREK & .255 & .102 & .235 & 2.498 & .014 \\
\hline & HARGA & .327 & .137 & .253 & 2.393 & .019 \\
\hline & $\begin{array}{l}\text { KUALITAS } \\
\text { PRODUK }\end{array}$ & .358 & .106 & .337 & 3.369 & .001 \\
\hline
\end{tabular}

Tabel 11, dapat dirumuskan model persamaan regresi linear berganda sebagai berikut:

Y= 0,255Citra Merek + 0,327Harga + 0,358Kualitas Produk +e

Model persamaan regresi yang dapat dituliskan dari hasil tersebut dalam bentuk persamaan regresi standardized adalah sebagai berikut:
1. Koefisien regresi citra merek $\left(\mathrm{X}_{1}\right)$ sebesar 0,102 memberikan arti bahwa citra merek $\left(\mathrm{X}_{1}\right)$ berpengaruh positif terhadap loyalitas konsumen Dunkin Donuts Manado Town Square (Y). Hal ini menunjukkan bahwa dengan penambahan satu satuan citra merek, maka akan terjadi peningkatan loyalitas konsumen sebesar 0,255 dan begitupun sebaliknya.

2. Koefisien regresi harga $\left(X_{2}\right)$ sebesar 0,137 memberikan arti bahwa harga $\left(\mathrm{X}_{2}\right)$ berpengaruh positif terhadap loyalitas konsumen Dunkin Donuts Manado Town Square (Y). Hal ini menunjukkan bahwa dengan penambahan satu satuan harga, maka akan terjadi peningkatan loyalitas konsumen sebesar 0,327 dan begitupun sebaliknya.

3. Koefisien regresi kualitas produk $\left(\mathrm{X}_{3}\right)$ sebesar 0,106 memberikan arti bahwa kualitas produk $\left(\mathrm{X}_{3}\right)$ berpengaruh positif terhadap loyalitas konsumen Dunkin Donuts Manado Town Square (Y). Hal ini menunjukkan bahwa dengan penambahan satu satuan kualitas produk, maka akan terjadi peningkatan loyalitas konsumen sebesar 0,358 dan begitupun sebaliknya.

\section{Uji Hipotesis}

\section{Uji Simultan (Uji F)}

Uji simultan (uji F) ini dilakukan untuk mengetahui apakah variabel bebas (independen) secara serempak atau bersamasama mempunyai pengaruh yang signifikan terhadap variabel terikat (dependen).

\begin{tabular}{|c|c|c|c|c|c|c|}
\hline Model & & $\begin{array}{c}\text { Jumlah } \\
\text { Kuadrat }\end{array}$ & $\begin{array}{c}\text { Derajat } \\
\text { Bebas }\end{array}$ & $\begin{array}{c}\text { Kuadrat } \\
\text { Rata-rata }\end{array}$ & $\mathrm{F}$ & Sig. \\
\hline \multirow[t]{3}{*}{1} & Regresi & 20.726 & 3 & 6.909 & 30.113 & .000 \\
\hline & Nilai Sisa & 21.107 & 92 & .229 & & \\
\hline & Total & 41.833 & 95 & & & \\
\hline
\end{tabular}

Dari hasil analisis regresi dapat diketahui bahwa hasil pengujian simultan (uji F) menunjukkan nilai signifikansi (sig) sebesar 0,000. Karena nilai signifikansi (sig) jauh lebih kecil dari 0,05 maka model regresi dapat digunakan untuk memprediksi loyalitas 
konsumen atau dapat dikatakan bahwa citra merek, harga, dan kualitas produk secara bersama-sama berpengaruh terhadap loyalitas konsumen. Sehingga hipotesis yang menyatakan citra merek, harga, dan kualitas produk secara bersama-sama berpengaruh positif terhadap loyalitas konsumen dapat diterima.

\section{Uji Parsial (Uji T)}

Uji T dilakukan untuk mengetahui pengaruh masing-masing atau secara parsial variabel independen yaitu citra merek, harga, dan kualitas produk terhadap variabel dependen yaitu loyalitas konsumen.

Tabel 13. Hasil Perhitungan Uji T

\begin{tabular}{llccccc}
\hline \multicolumn{5}{c}{ Kesalahan } \\
& $\mathrm{B}$ & Std. & Beta & $\mathrm{T}$ & Sig. \\
\hline 1 Konstan & .064 & .437 & & .146 & .884 \\
& CITRA MEREK & .255 & .102 & .235 & 2.498 & .014 \\
\multicolumn{2}{l}{ HARGA } & .327 & .137 & .253 & 2.393 & .019 \\
\multicolumn{2}{l}{ KUALITAS PRODUK } & .358 & .106 & .337 & 3.369 & .001 \\
\hline \multicolumn{2}{l}{ Sumber: Hasil olahan SPSS 22 (Statistical Package for Social Science 22), 2019}
\end{tabular}

a. Variabel citra merek berpengaruh positif dan signifikan secara parsial terhadap loyalitas konsumen, hal ini terlihat dari nilai t sebesar 2,498 dan nilai signifikan $0,014<0,05$. Artinya, jika variabel citra merek ditingkatkan satu satuan maka loyalitas konsumen akan meningkat sebesar 0,255.

b. Variabel harga berpengaruh positif dan signifikan secara parsial terhadap loyalitas konsumen, hal ini terlihat dari nilai t sebesar 2,393 dan nilai signifikan $0,019<0,05$. Artinya, jika variabel harga ditingkatkan satu satuan maka loyalitas konsumen tidak akan meningkat sebesar 0,327.

c. Variabel kualitas produk berpengaruh positif dan signifikan secara parsial terhadap loyalitas konsumen, hal ini terlihat dari nilai t sebesar 3,369 dan nilai signifikan $0,001<0,05$. Artinya, jika variabel kualitas produk ditingkatkan satu satuan maka loyalitas konsumen akan meningkat sebesar 0,358.

\section{Koefisien Determinasi $\left(\mathbf{R}^{\mathbf{2}}\right)$}

Koefisien determinasi digunakan untuk mengetahui tinggi rendahnya variabel-variabel bebas terhadap variabel terikatnya.

\begin{tabular}{lcccc}
\multicolumn{5}{l}{ Tabel 14. Hasil Perhitungan Koefisien Determinasi $\left(\mathbf{R}^{2}\right)$} \\
\hline Model & $\mathrm{R}$ & $\begin{array}{c}\mathrm{R} \\
\text { Kuadrat }\end{array}$ & $\begin{array}{c}\text { R Kuadrat } \\
\text { yang } \\
\text { Disesuaikan }\end{array}$ & Kesalahan Standar dari Penduga \\
\hline 1 & .704 & .495 & .479 & .47898 \\
\hline
\end{tabular}

Sumber: Hasil olahan SPSS 22 (Statistical Package for Social Science 22), 2019
Tabel 14 menunjukkan bahwa hasil perhitungan dengan menggunakan SPSS 22 dapat diketahui bahwa koefisien determinasi (Adjusted R Square) yang diperoleh sebesar 0,479. Hal ini berarti 47,9\% loyalitas konsumen dapat dijelaskan oleh variabel citra merek, harga, dan kualitas konsumen, sedangkan sisanya yaitu $52,1 \%$ loyalitas konsumen dipengaruhi oleh variabel-variabel lainnya yang tidak diteliti dalam penelitian ini. Variabel lain yang dimaksud yaitu promosi, lokasi, pelayanan, kenyamanan, garansi, dan lain-lain.

\section{KESIMPULAN DAN SARAN}

\section{Kesimpulan}

Faktor kualitas produk merupakan faktor yang paling berpengaruh terhadap loyalitas konsumen Dunkin' Donuts Manado Town Square. Sedangkan faktor yang memiliki pengaruh paling rendah terhadap loyalitas konsumen adalah faktor citra merek. Hal ini berarti bahwa jika kualitas produk Dunkin' Donuts mengalami perubahan maka loyalitas konsumen Dunkin' Donuts juga akan berubah. Citra merek, harga, dan kualitas produk berpengaruh positif terhadap loyalitas konsumen Dunkin' Donuts Manado Town Square. Citra merek, harga, dan kualitas produk secara bersama-sama berpengaruh terhadap loyalitas konsumen. Lalu secara individu, citra merek, harga, dan kualitas produk berpengaruh positif dan signifikan terhadap loyalitas konsumen. Citra merek, harga, dan kualitas produk berpengaruh sebesar 47,9 persen terhadap loyalitas konsumen.

\section{Saran}

Berdasarkan penelitian yang telah dilakukan, maka peneliti mengemukakan beberapa saran. Saran-saran ini diharapkan dapat berguna bagi pemilik usaha Dunkin' Donuts. Bagi manajemen usaha ini harus tetap mempertahankan citra merek yang baik di mata konsumen, tetap memberikan harga yang sepadan dengan apa yang konsumen dapatkan, dan menjaga atau meningkatkan kualitas produk Dunkin' Donuts agar konsumen tetap loyal terhadap Dunkin' Donuts. 
DAFTAR PUSTAKA

Sangadji dan Sopiah. 2013. Perilaku Konsumen Pendekatan Praktis. Andi: Yogyakarta.
Sugiyono. 2009. Metode Penelitian Kuantitatif, Kualitatif dan R\&D. Alfabeta: Bandung.

Tjiptono. 2008. Strategi Pemasaran. Andi: Yogyakarta. 